\title{
The Politics of the UN Convention on Migrant Workers' Rights
}

Antoine Pécoud ${ }^{*}$

DOI: $10.21827 / 59 \mathrm{db} 6983 \mathrm{~b} 848 \mathrm{~b}$

\author{
Keywords \\ HUMAN RIGHTS; INTERNATIONAL MIGRATION; INTERNATIONAL LAW; \\ UNITED NATIONS; GLOBAL MIGRATION GOVERNANCE
}

\begin{abstract}
The International Convention on the Protection of the Rights of All Migrant Workers and Members of Their Families (ICMW) was adopted in 1990 by the United Nations, but has been ratified by 51 States only, and by no major Western migration-receiving State. This article outlines two interpretations of this low ratification record. On the one hand, it can be understood as puzzling because Western liberal democracies support human rights and because the ICMW does not call for new rights that would not already exist in domestic law or in other international human rights instruments. On the other hand, it can be understood as logical because, from a cost-benefit perspective, the rights of migrants are difficult to reconcile with market logics in destination countries and because there are structural economic forces that make it difficult to reach multilateral agreements on migrant workers' rights. This article further argues that these legal and socio-economic arguments do not exhaust the issue and that the current situation of the ICMW is to a large extent the product of political factors, particularly of the lack of political support for migrants' rights at the international and national levels.
\end{abstract}

\section{Introduction}

Adopted in 1990 by the United Nations (UN) General Assembly, the International Convention on the Protection of the Rights of All Migrant Workers and Members of Their Families $(\mathrm{ICMW})^{1}$ remains one of the most neglected treaties in international human rights law. It is presented, by the Office of the UN High Commissioner for Human Rights, as one of the 'core international human rights treaties', which include better-known conventions, such as the 1966 Covenants, ${ }^{2}$ the 1989 Convention on the Rights of the Child and the 1979 Convention on the Elimination of All Forms of Discrimination against Women. ${ }^{4}$ Yet, compared to these treaties, the ICMW is under-ratified: at the time of writing (June 2017) only 51 States have ratified it and, most notably, no important Western destination country has done so. Therefore, it is arguable that the ICMW has so far struggled to achieve what it was meant

Professor of sociology, University of Paris $13 \&$ research associate, CERI/Sciences Po. Email: antoine.pecoud@univ-paris13.fr

1 UN General Assembly, International Convention on the Protection of the Rights of All Migrant Workers and Members of Their Families, 18 December 1990, (69th plenary meeting) A/RES/45/158.

2 UN General Assembly, International Covenant on Civil and Political Rights (1966) 999 UNTS 171 (ICCPR); UN General Assembly, International Covenant on Economic, Social and Cultural Rights (1966) 993 UNTS 3 (ICESCR).

3 UN General Assembly, Convention on the Rights of the Child, 20 November 1989, (61st plenary meeting) A/RES/44/25.

4 UN General Assembly, Convention on the Elimination of All Forms of Discrimination against Women, 18 December 1979, (107th plenary meeting) A/RES/34/180. 
to do, namely increase the protection of migrant workers' rights by establishing widelyaccepted standards in this subfield of human rights law.

This article argues that this situation can be interpreted as both puzzling and logical. It is puzzling because Western liberal democracies traditionally support human rights and because the ICMW does not, contrary to widespread misperceptions, call for a new set of rights that would otherwise not exist in domestic law or in other international human rights instruments. Therefore, there are no legal obstacles that could justify the reluctance to ratify and implement the Convention, at least in the well-established Etats de droit that are home to a large share of the world's migrant population. Yet, it can also be understood as logical: from a cost-benefit perspective, the rights of migrants are difficult to reconcile with market logics in destination countries and there are structural economic forces that make it very difficult to reach multilateral agreements on migrant workers' rights. In particular, the socio-economic imbalances between origin and destination States make reciprocal arrangements almost impossible.

I will also argue, however, that this seemingly binary opposition should be challenged and that the low ratification record of the ICMW should be understood as a fundamentally political matter. It is above all for political reasons, rather than legal or socio-economic reasons, that the ICMW suffers from such a low ratification record. This is evident in the way the UN and other intergovernmental organisations address migration issues, as well as in the case of 'in-between' States, which are not clearly positioned on the origin/destination State divide; some of them have ratified, while others, which could have, ultimately did not. In other words, while there are fundamental structural forces (of a legal or socioeconomic nature) that explain why States may accept or reject the ICMW, there are also more contingent political factors which play a role in shaping the current fortunes of the Convention. Importantly, this also means that future perspectives remain, to some extent, open and that an increase in the popularity of the ICMW amongst States cannot be excluded.

\section{History and Content of the ICMW}

The International Labour Organisation (ILO) first addressed the rights of migrant workers at the international level. This organisation was created in 1919, at the time of the Versailles treaty and the establishment of the League of Nations, and its original Constitution already mentioned the 'protection of the interests of workers when employed in countries other than their own'. The ILO is characterised by its so-called tripartism, as it engages not only with governments but also with unions and employers. The interest in migration was thus motivated by the objective of increasing labour standards and by the ambition to lessen the downward pressure that results from competition between national and foreign workers; protecting migrant workers' rights was a strategy to protect all workers' rights. ${ }^{5}$ Throughout the $20^{\text {th }}$ century, the ILO adopted conventions pertaining to labour migration, which have had mixed success in terms of ratification. ${ }^{6}$

The objectives pursued by the ICMW are very much consistent with the ILO's efforts and the corresponding UN Convention. The ICMW logically builds upon earlier treaties adopted by this specialised agency. However, this was not a smooth process as the ILO believed that the issue should remain solely within its realm and was reportedly

5 Hasenau, M, "ILO Standards on Migrant Workers: The Fundamentals of the UN Convention and Their Genesis" 25(4) International Migration Review (1991), 690-692.

6 See in particular: ILO, Convention concerning Migration for Employment Convention (Revised), (1949) No. 97; ILO, Convention concerning Migrations in Abusive Conditions and the Promotion of Equality of Opportunity and Treatment of Migrant Workers (1975) No 143. 
reluctant to cooperate with the UN. ${ }^{7}$ While incorporating a labour protection mandate, the ICMW was also born out of a distinct human rights approach. As noted above, it is indeed one of the core international human rights law instruments and reflects the need to more explicitly articulate the relation between the inclusive universality of human rights and the exclusive nature of State sovereignty. While human rights are to protect 'everybody' (whether citizens or migrants), it progressively became clear that non-nationals were not systematically perceived as part of this category. ${ }^{8}$

This explains why the ICMW speaks of migrant workers. Today, this term is used less frequently: while the ILO still speaks of migrants as workers, ${ }^{9}$ many other actors and observers speak of migrant rights or of the human rights of migrants, ${ }^{10}$ sometimes with an emphasis on certain categories of migrants (for instance irregular migrants, trafficked migrants, migrant women). This is not just a matter of words, as this semantic change has political implications. The emphasis on migrant workers frames migration issues within an internationally-constructed perspective on labour protection; migrant workers' rights are understood as a labour issue of importance to all, as the rights of national workers cannot be dissociated from the rights of their foreign co-workers. This challenges the national divide between citizens and foreigners. In contrast, by omitting the word worker, the notion of migrant rights may be understood as placing more weight on the foreignness of migrants and on the almost ontological difference between them and citizens. Migrants are then portrayed as non-nationals or outsiders who should benefit from universal human rights, but whose interests may nevertheless diverge from those of nationals.

At the same time, the emphasis on human rights (and not solely labour rights) is crucial in terms of the protection of migrants who are not active on the labour market or whose presence is only partly related to their working capacity. The ICMW refers to this category of people as 'members of the families' of migrant workers, yet, one can think of other 'non-working' categories of migrants whose significance has increased in scholarly and policy debates since the Convention was adopted (for instance forced or trafficked migrants). Nevertheless, and as discussed below, much of the current academic and policy discussions on the ICMW focus precisely on the trade-off between the rights of nationals and non-nationals, with the former being opposed to the latter. This 'national' take on the topic militates against support for the ICMW. As this article will argue, ratification of the Convention is less likely if citizens perceive this as the mere granting of rights to outsiders; this may easily generate hostile reactions along an 'us and them' divide. If, by contrast, the ICMW is framed in an international labour perspective and as an issue that benefits all workers by lessening the competition between them, ratification may appear as beneficial not only for foreigners but also for citizens. Yet, this second internationalist perspective is, arguably, decreasingly popular, which does not favour the ICMW.

This feature of the ICMW, at the crossroads between labour protection and human rights, is important to understand the current situation. These different frameworks indeed

7 Battistella, G, "Migration and human rights: the uneasy but essential relationship" in Cholewinski, R, de Guchteneire, P, and Pécoud, A, eds, Migration and Human Rights: The United Nations Convention on Migrant Workers' Rights (Cambridge University Press, New York, 2009), 53-54. The special role of the ILO in the protection of migrant workers' rights was recognized in the ICMW, which foresees that this agency be consulted by the UN on these matters (see Article 74).

8 Groenendijk, K, "Introduction" in Bohusz, B, Cholewinsky, R, Cygan, A and Szyszczak, T, eds, Irregular Migration and Human Rights: Theoretical, European, and International Perspectives (Leiden, Martinus Nijhoff, 2004), xix.

9 ILO, ILO Multilateral Framework on Labour Migration: Non-binding principles and guidelines for a rights-based approach to labour migration (ILO, Geneva, 2006).

10 Amnesty International, Living in the Shadows: A primer on the human rights of migrants (Amnesty International, London, 2006). 
mobilise different actors. Labour protection is an issue mainly for unions, whereas human rights are predominantly supported by civil society organisations and NGOs. Grange and d'Auchamp report that human rights NGOs, which traditionally play a key role in the drafting of human rights conventions, were largely absent in the case of the ICMW. The human rights of migrants were not a priority at the time, as the emphasis was on civil and political rights (rather than on social and economic rights, which is the focus of the ICMW); even the rights of refugees were perceived as a humanitarian (and not a human rights) topic. ${ }^{11}$ This resulted in a lack of civil society support for the Convention. Grange and d'Auchamp further noted that this also led to the strong presence of faith-based organisations, which were among the few to be interested in migration and remain, even today, at the forefront of the campaign for the ICMW and for migrants' rights in general.

Another key feature of the history of the ICMW is the leading role of non-Western States, to the extent that it is sometimes known as a 'G-77 treaty'. ${ }^{12}$ At the diplomatic level, the governments of Mexico and Morocco were very active throughout the drafting process. This is unusual as international and diplomatic debates over human rights tend to be mostly pushed forward by Western developed countries. Indeed, migrants' rights is probably one of the only fields of human rights that enjoy greater support from the 'South' than from the 'North'. One of the reasons for this is that some key origin countries saw the ICMW as a useful standard to protect their citizens abroad. ${ }^{13}$ This nevertheless raises the question of the universality of human rights, as it appears that those rights that are not backed by the North tend to be contested and not viewed as truly 'universal'. That being said, initial proposals by sending countries were strongly resisted, which gave a central role to a number of Western States in searching for more consensual formulations in the elaboration of the ICMW. ${ }^{14}$

Content-wise, the ICMW provides a more precise and specific interpretation of the way human rights should be applied to migrant workers. This corresponds to other treaties, which also target other potentially vulnerable groups (women, children and, more recently, disabled people, for example). While it codifies some new rights specific to the condition of migrants (such as the right to transfer remittances or to have access to information on the migration process), it mostly relies upon already-existing rights, which were formulated in earlier international human rights instruments but whose application to migrant workers had not been detailed in a specific way. Of particular relevance here is the ICMW's explicit inclusion of undocumented migrants within its scope of application. This is one of the most controversial issues. Logically, undocumented migrants are human beings and, as such, are protected by international human rights law; the ICMW puts this on paper, in a way that earlier treaties did not. ${ }^{15}$ However, this remains problematic as

11 Grange, M, and d'Auchamp, M, "Role of civil society in campaigning for and using the ICRMW" in Cholewinski, R, de Guchteneire, P, and Pécoud, A, eds, Migration and Human Rights: The United Nations Convention on Migrant Workers' Rights (Cambridge University Press, New York, 2009), p. 72.

12 LaViolette, N, "The Principal International Human Rights Instruments to which Canada has not yet adhered", 24, Windsor Yearbook of Access to Justice (2006), 303-305.

13 On Mexico, for example, see Diaz, G, and Kuhner, G, "Mexico's role in promoting an implementing the ICRMW" in Cholewinski, R, de Guchteneire, P, and Pécoud, A, eds, Migration and Human Rights: The United Nations Convention on Migrant Workers' Rights (Cambridge University Press, New York, 2009); on the Philippines, see Piper, N, "Obstacles to, and opportunities for, ratification of the ICRMW in Asia" in Cholewinski, R, de Guchteneire, P, and Pécoud, A, eds, Migration and Human Rights: The United Nations Convention on Migrant Workers' Rights (Cambridge University Press, New York, 2009).

14 These were in particular the so-called MESCA countries: Finland, Greece, Italy, Norway, Portugal, Spain and Sweden.

15 Bosniak, L, "Human Rights, State Sovereignty and the Protection of Undocumented Migrants under the International Migrant Workers Convention" 25(4) International Migration Review (1991), 738-739. 
destination States are required to guarantee the rights of people they may not have wanted to admit in the first place and whom they may want to remove, if necessary through coercive measures like detention or expulsion. States tend to find it very difficult to respect migrants' rights when trying to remove undocumented migrants and, in practice, these measures regularly lead to human rights violations. ${ }^{16}$

After adoption by the UN General Assembly on 18 December 1990, the Convention was open to ratification by States. Twenty ratifications were necessary in order for the ICMW to enter into force; this threshold was not reached until 2003. This low ratification record was not entirely expected. Immediately after adoption it was believed within the UN that the ICMW would enter into force in 1991 or 1992. Even less optimistic observers believed that the MESCA-countries would ratify; other countries Canada, Venezuela and Argentina - were also expected to do so. ${ }^{17}$

Overall, there has not been much research on the ICMW. This means that any understanding as to why States do not ratify it is, at best, only partial. Nevertheless, debates among researchers, policymakers and civil society actors tend to be polarised around two diverging interpretations of this situation, which in turn correspond to two different views of what should be done. In the first interpretation, the ICMW's low ratification record is viewed as a puzzling mistake that can and should be corrected. It results from an array of factors of differing nature, which somehow prevent the full recognition of the usefulness of the ICMW and of the legitimacy of migrants' rights. By contrast, the second interpretation considers that States' refusal to ratify is logical given the structural economic and political forces that shape immigration policy. On this view, the ICMW is a deeply flawed treaty, which is unable to increase or guarantee migrants' access to their rights. In what follows, I examine in greater details these two interpretations.

\section{The 'Puzzling' Legal/Technical Interpretation}

It has often been observed that the ICMW is overall close to existing legal standards, especially in Western democracies. If States were to become interested in ratifying, they would find this relatively easy, because their own legislation already contains most of the rights foreseen by the ICMW. ${ }^{18}$ This is documented by several case studies, which assess the compatibility of the ICMW with the legal provisions that exist in other (already ratified) international treaties, as well as in domestic law. One of the most detailed analyses found that 'Belgian national law is (in practice) highly compatible with the provisions of the Convention'. ${ }^{19}$ Oger $^{20}$ and Touzenis ${ }^{21}$ reach more or less the same

16 See for example Vohra, S, "Detention of Irregular Migrants and Asylum Seekers" in Cholewinski, R, Perruchoud, R, and MacDonald, E, eds, International Migration Law: Developing Paradigms and Key Challenges, (T.M.C. Asser Press, The Hague, 2007).

17 For an early perspective on the ICMW by observers closely associated to its elaboration, see Hune, S, and Niessen, J, "The First UN Convention on Migrant Workers" 9 Netherlands Quarterly of Human Rights (1991) 2 .

18 MacDonald, E and Cholewisnki, R, "The ICRMW and the European Union" in Cholewinski, R, de Guchteneire, P, and Pécoud, A, eds, Migration and Human Rights: The United Nations Convention on Migrant Workers' Rights (Cambridge University Press, New York, 2009), 364.

19 Vanheule, D, Foblets, MC, Loones, S and Bouckaert, S, "The Significance of the UN Migrant Workers' Convention of 18 December 1990 in The Event of Ratification by Belgium" 6(4) European Journal of Migration and Law (2004) 285, 320.

20 Oger, H, "The French Political Refusal on Europe' behalf" in Cholewinski, R, de Guchteneire, P and Pécoud, A, eds, Migration and Human Rights. The United Nations Convention on Migrant Workers' Rights (Cambridge University Press, Cambridge, 2009).

21 Touzenis, K, "Migration and Human Rights in Italy: Prospects for the ICRMW" in Cholewinski, R, de Guchteneire, P and Pécoud, A, eds, Migration and Human Rights. The United Nations Convention on Migrant Workers' Rights (Cambridge University Press, Cambridge, 2009). 
conclusions for France and Italy. These conclusions are in line with the commitment to human rights that characterise Western countries, and with their good ratification record of other international human rights law treaties. Why, then, would Western advanced democracies prove so unwilling to ratify the ICMW? How can we understand the low ratification record of the ICMW in this context? According to the 'puzzling' interpretation, the answer lies in the misperceptions that surround the Convention, the technical difficulties it raises, and in the fact that States have only recently come to recognise that migration is an issue for multilateral cooperation that requires international standards.

It is widely reported that the actual content of the ICMW is the object of many misunderstandings. Governments would for instance often wrongly believe that ratification of the ICMW would force them to change their legislation. ${ }^{22}$ According to MacDonald and Cholewinski ${ }^{23}$, this is the case in Europe, where States claim that they have legal objections to the ICMW; but the same authors show that this argument does not hold up under closer examination, as ratification would not bring major changes in their immigration policies. In Asia, Piper writes that the ICMW is viewed as 'an instrument for liberal immigration policy', and that it would interfere with States' sovereign right to control and regulate migration. ${ }^{24}$ From an advocacy perspective, the key issue then lies in correcting these mistaken beliefs. These misunderstandings can also be linked the complexity of the ICMW: arguably a long and detailed treaty, it addresses a wide range of issues, which encompass not only labour protection, but also health policy and the educational system for example. This raises technical obstacles, as ratification would require a high level of coordination among a broad range of State and non-State actors. As Cholewinski noted almost twenty years ago, 'technical questions alone ... may prevent many states from speedily accepting [the ICMW's] provisions' ${ }^{25}$. This complexity comes with a high level of ignorance surrounding the ICMW. Even among unions, NGOs and other migration-related actors and institutions, few people are familiar with the Convention and even fewer are capable of mastering its complexity and assessing the issues raised by a potential ratification.

Time would constitute an important factor in this respect. In many countries, migration is - or is perceived as - a relatively new phenomenon, to the extent that governments still find it difficult to apprehend all its implications and to evaluate the consequences of ratifying a UN convention in this field. For example, despite important migration flows, many Asian States still view themselves as non-migration countries, and hardly see the need for designing a comprehensive immigration policy ${ }^{26}$. To some extent, this also applies to certain European countries, including inter alia Germany ${ }^{27}$, Poland and Norway ${ }^{28}$. This may however be changing as more and more States are confronted with migration-related problems. States may be encouraged to recognise the key role played by immigration, and the need to think about a political strategy in this field - a process in which the ICMW may prove useful.

22 De Guchteneire, P, and Pécoud, A, "Introduction: the UN Convention on Migrant Workers' Rights" in Cholewinski, R, de Guchteneire, $\mathrm{P}$ and Pécoud, A, eds, Migration and Human Rights. The United Nations Convention on Migrant Workers' Rights (Cambridge University Press, Cambridge, 2009).

23 MacDonald, E and Cholewinski, R, supra nt 18.

24 Piper, N, supra nt 13, 176.

25 Cholewinsky, R, Migrant Workers in International Human Rights Law: Their Protection in Countries of Employment (Clarendon Press, Oxford, 1997), 201.

26 Piper, N, supra nt 13.

27 Hillman, F and Klekowski von Koppenfels, A, "Migration and Human Rights in Germany" in Cholewinski, R, de Guchteneire, $\mathrm{P}$ and Pécoud, A, eds, Migration and Human Rights. The United Nations Convention on Migrant Workers' Rights (Cambridge University Press, Cambridge, 2009).

28 MacDonald, E and Cholewinski, R, supra nt 18. 
There a few indications that this may already be taking place, at least to a small extent. Even if not ratified, the ICMW can indeed play a potentially useful role, either in inspiring policy reforms or in catalysing forces among migration-related actors. In the UK, for example, Bernard Ryan reports that the Convention enjoys the support of a range of non-State actors (unions, civil society), which use it as a standard in their input to policymaking processes; as a result, the ICMW has indirectly influenced recent political debates and policy reforms. ${ }^{29}$ Other authors call for this process to start: in the United States, Beth Lyon argues that, while ratification itself is unlikely, at least opening a debate on the ICMW could help push forward political debates on migration. ${ }^{30}$ This points to the often-neglected catalysing function of the Convention. Given its wide-ranging scope and international nature, it has the potential to unite different actors in different countries, and serve as a rallying point ${ }^{31}$. Debates on the ICMW tend to focus on its ratification record, and conclude that, if few States have ratified it, then it has failed to make a difference. While this assessment is correct in many respects, it nevertheless underestimates its role in shaping the way migration is discussed by State and non-State actors. In a world in which migration is increasingly debated, and by an increasing range of actors, this function of the ICMW may be expected to become increasingly relevant.

Patrick Taran elaborates on this further by arguing that migration has long constituted a black hole in global governance. ${ }^{32}$ The mobility of labour is directly linked to economic globalisation, but lacks an international political framework that would make sure labour mobility takes place in a way that is both economically beneficial and respectful of States' commitments to human rights and moral values. Over the past decades, States have tried to establish so-called global governance mechanisms to address transnational issues, such as trade or climate change. Migration has not been a priority even if, again, this may be changing: the interest in 'global migration governance' has increased since approximately 2000 with many international and multilateral initiatives. ${ }^{33}$ The UN Special Rapporteur on the human rights of migrants, François Crépeau, thus, calls for a human-rights-based 'regime' for international migration:

Migration is a complex phenomenon, which affects most, if not all, States in the world and is closely linked to other global issues, such as development, health, environment and trade. States have created international frameworks for such other global issues, recognizing the advantages of regulation at the international level, but despite the existence of legal frameworks on migration issues, a comprehensive framework for migration governance is still lacking. Certain aspects of migration are more frequently discussed at the bilateral and multilateral levels, such as the connections between migration and development. However, given that migration is

${ }^{29}$ Ryan, B, "Policy on the ICRMW in the United Kingdom" in Cholewinski, R, de Guchteneire, P and Pécoud, A, eds, Migration and Human Rights. The United Nations Convention on Migrant Workers' Rights (Cambridge University Press, Cambridge, 2009).

30 Lyon, B, "The Unsigned United Nations Migrant Workers Convention: An Overlooked Opportunity to Change the Brown Collar Migration Paradigm" 42 New York University Journal of International Law and Politics (2010) 389.

31 Grange, $\mathrm{M}$ and d'Auchamp, M, supra nt 11.

32 Taran, P, "The Need for a Rights-Based Approach to Migration in the Age of Globalization" in Cholewinski, R, de Guchteneire, P \& Pécoud, A, eds, Migration and Human Rights. The United Nations Convention on Migrant Workers' Rights (Cambridge University Press, Cambridge, 2009).

33 One can for example mention the organisation of high-level international conferences on migration, like the UN High-Level Dialogue (in 2006, 2013 and most likely 2019 as well) or the Global Forum on Migration and Development (which has taken place every year since 2007), see Pécoud, A, Depoliticising Migration. Global Governance and International Migration Narratives (Palgrave, Basingstoke, 2015). 
in essence a fundamentally human phenomenon, the Special Rapporteur notes the need for an international migration governance regime strongly focused on human rights. $^{34}$

The possible emergence of an 'international migration governance regime' could be favourable to the ICMW, as cooperation requires shared norms and standards - precisely what the Convention has to offer.

In sum, according to this first interpretation of the low ICMW ratification record, the core problems lie in the unpreparedness of States, which are unaware of its provisions and unable to implement it properly because of their lack of experience with migration. This, however, is bound to change and the compatibility of the Convention with existing laws could eventually make it quite easy to ratify- thereby correcting the odd difference between the ICMW and other human rights conventions.

\section{The 'Logical' Cost-Benefit Interpretation}

If one looks at the ICMW from another angle, namely from a cost-benefit perspective, its low ratification record looks very different. It is no longer a strange mistake that can be corrected by time or awareness-raising efforts, but rather the consequence of fundamental imbalances in migration dynamics, which are deeply unsupportive of migrants' access to human rights and, unfortunately, unlikely to change in the near future.

The central assumption behind this cost-benefit perspective is that rights have a cost, and that States are unlikely to commit to migrants' rights if this does not yield benefits. The problem is that, in the current migration situation, ratification would entail high costs and bring minimal benefits to destination countries. This is mainly due to the asymmetry between destination and origin States: migrants move predominantly from relatively poor to relatively richer regions (whether at the regional or global level), which means that the ICMW has unequal implications for the two sides of the migration process. Even if it foresees obligations for the origin countries (such as providing pre-migration information), it is mostly destination countries that have to implement the Convention's provisions. This imbalance leads to a lack of reciprocity: if both origin and destination States were to ratify, this would be beneficial for the former (whose citizens living abroad would enjoy more rights), but much less for the latter (which does not have many emigrants in need of protection abroad). If all States were both origin and destination countries, they would be equally concerned and ratification could support a mutual guarantee that would be of interest to all; but the nature of migration flows makes this unlikely.

This is a well-known problem when it comes to any kind of cooperation over migration issues, especially when compared to other fields of international cooperation such as trade; as Timothy J. Hatton writes:

Migration is much more of a one-way street than is trade. While, in a multilateral context, trade balances have to add up roughly to zero, net migration balances do not. If rich and poor countries were gathered around the negotiating table, it is difficult to see how improved terms of access to the labour markets of the poor(er) countries could be of equal value to similar conditions of access granted by rich(er) countries in return. Indeed, even the poorer countries may have little incentive to

34 UN General Assembly, Report of the Special Rapporteur on the human rights of migrants, 5 August 2013 (68th Session) A/68/283, 2013, 3-4. 
come to the bargaining table. Those in poor countries who have the greatest incentive to support such negotiations are precisely those who wish to leave. ${ }^{35}$

There is empirical evidence that supports this analysis. South Africa, for example, sees no reason to ratify a Convention that would benefit migrants from its poorer neighbours. ${ }^{36}$ Nicola Piper also notes that, in Asia, this leads to a competition between origin States: poor countries are reluctant to ratify because this would signal a rights-consciousness that would jeopardise their relationships with rich destination countries (particularly the Gulf States).$^{37}$ In other words, the two sides of the migration process are not on an equal footing and, given the socioeconomic and political imbalances between them, destination countries can afford to impose conditions on origin regions, which have very little bargaining power to impose respect for the ICMW's provisions.

Another implication of this imbalance is that, from a supply and demand perspective, destination countries have access to an almost unlimited pool of potential migrants from poorer regions. They have therefore no incentive to offer rights, as migrants are likely to come anyway, no matter the level of protection they are afforded. This makes for an unfavourable context, which will change only in case of a shortage of migrants. Indeed, this is what happens with skilled migrants, who are much less numerous and hence much more sought-after. Destination States are therefore obliged to grant rights if they want to attract them. Another difference between unskilled and skilled migrants is the unequal economic benefits they are expected to bring to the destination country: unskilled migrants are typically thought to generate low profits, which makes an investment in granting them rights illogical; by contrast, skilled workers boost the economy, which justifies a generous rights policy.

This leads Martin Ruhs to argue that migrant rights cannot be apprehended as a matter of universal legal standards; they should rather be understood as an economic variable in immigration policy. ${ }^{38}$ States would then decide how many rights to grant to the foreigners they welcome, depending upon their overall strategy. For example, a State can decide to welcome many migrants, but is then unlikely to grant them extended rights (as this would be too costly). Opening the doors to skilled and economically profitable migrants could, on the contrary, be accompanied by a generous rights policy. In this political economy logic, the Convention is bound to fail: it foresees a horizontal distribution of rights to all migrants, whatever their skill level or numbers, whereas access to rights would on the contrary depend upon market mechanisms - leading to vertical hierarchy between migrants and between the range of rights they enjoy. As Srdjan Vucetic writes, the ICMW is unpopular because it 'stipulates too many rights for too many people'. ${ }^{39}$

This argument is both scientific and normative. Ruhs claims that this trade-off between numbers and rights is empirically verifiable; for instance, European States are generous in terms of rights and therefore opt for tight immigration policy, whereas the opposite holds true for the Gulf States. Measuring such variables as 'rights' and 'openness'

35 Hatton, TJ, "Should We Have a WTO for International Migration?" 22(50) Economic Policy (2007), 339, 364.

36 Crush, J, Williams, V and Nicholson, P, "Migrants' Rights after Apartheid: South African Responses to the ICRMW" in Cholewinski, R, de Guchteneire, $\mathrm{P}$ and Pécoud, A, eds, Migration and Human Rights. The United Nations Convention on Migrant Workers' Rights (Cambridge University Press, Cambridge, 2009).

37 Piper, N, supra nt 13.

38 Ruhs, M, The Price of Rights. Regulating International Labor Migration (Princeton University Press, Princeton, 2013).

39 Vucetic, S, "Democracies and International Human Rights: Why is There No Place for Migrant Workers?" 11(4) International Journal of Human Rights (2007), 403. 
is uneasy however and, inevitably, such empirical findings can be contested, as changes in variables will lead to different outcomes. ${ }^{40}$ Politically, the normative implication of this trade-off is that States should design temporary labour migration programmes, which would enable more migration, but with less rights than what a treaty like the ICMW foresees. This would be in the interest of all, including of migrants, because more of them could then have access to employment opportunities abroad. ${ }^{41}$

This discussion amounts, in many respects, to the standard opposition between pragmatics (or realists) and idealists. While generous, those who support the ICMW would actually harm migrants' interests by asking for standards that are too high, which States are bound to resist. Real-world efforts in favour of migrants should then give up the Convention and limit migrants' rights to a core set of fundamental rights. The problem, of course, is that pragmatics' arguments tend to boil down to a vibrant plea for the status quo. Indeed, this political economy framework is useful to understand why migrants fail to enjoy rights. It is much less useful as a normative and programmatic agenda, because the very idea behind the ICMW - and behind the entire human rights philosophy - is precisely to go beyond the distribution of rights on the sole basis of wealth and power.

\section{The Politics of the ICMW}

Both the 'puzzling' legal/technical and the 'logical' cost-benefit interpretations display weaknesses. The first one is a little optimistic: indeed, evidence shows that even States such as France or Canada, with both a well-established Etat de droit and with a longstanding migration history, are reluctant to ratify the Convention. ${ }^{42}$ While arguments on the need for time and awareness-raising efforts were relevant at the time when the ICMW was drafted and adopted they prove less convincing today, as the deep resistance of States to this treaty becomes clearer. The second interpretation is based on the questionable assumption that ratification of the ICMW is costly because it would entail more rights for migrants. This makes sense in some destination States with a traditionally lower standard of human rights protection (such as in Asia or in the Gulf). However, it is less relevant in Western countries, in which - as noted above - existing laws already grant migrants the rights that are contained in the Convention. If the ICMW does not entail a rightsexpansiveness then the cost-benefit argument no longer holds true and the whole political economy argument regarding why States do not ratify collapses. Moreover, the costbenefit interpretation assumes that the ICMW improves the rights of migrants only; as suggested in the first section of this article, this is not the only way to frame the issue. One can posit that, by lessening the competition between foreign and national workers, the Convention may be beneficial for a majority of workers, whether migrant or otherwise.

This calls for recognising the political nature of the ICMW and its function as a symbol in the global politics of migration. Ratification is not only a legal or an economic issue, it is a political decision based on a rights-consciousness and embedded in the power relations between the different actors involved as well as in the worldviews that inspire migration policymaking. Technical arguments over the legal obligations contained in the

40 Cummins, $\mathrm{M}$ and Rodriguez, F, "Is There a Numbers versus Rights Trade- off in Immigration Policy? What the Data Say" 11(2) Journal of Human Development and Capabilities (2010) 281.

41 Such a recommendation fits into a broader and renewed interest in so-called guest worker systems, which were very popular in both the US and Western Europe until the early 70s. As Castles notes, however, it is unclear why such programmes are more successful today than in the past. A key lesson from recent history is that they inevitably lead some migrants to overstay, in which case the issue of their status and rights become quite complex, see Castles, S, "Guestworkers in Europe: A Resurrection?" 40(4) International Migration Review (2006), 741.

42 This is the case of France or Canada for example. 
ICMW or the additional costs it would entail for receiving States are certainly important, however, they tend to miss the point in this respect. In legal terms, the Convention may well not constitute an additional set of rights, particularly for those migrants who lawfully live in Northern countries with well-established Etats de droit; neither would it lead to a increase in the costs of labour migration. Yet, these legal and political considerations do not exhaust the issue: indeed, the ICMW is also (and, perhaps, above all) contested for political reasons, both at the domestic and at the international level.

Inside destination States, it constitutes a symbol for the recognition of migrants' rights, which is bound to encounter resistance given the widespread anti-immigration feelings that exist almost everywhere. Non-ratification of the ICMW can also be interpreted as a purely political (or electoral) problem. As foreigners, migrants are not citizens and (usually) cannot vote; ratification would then happen only if migrants' interests are understood as close to citizens', or if electorates were to express a solidarity with migrants and to call upon their governments to grant them rights. However, as long as this is not the case there is no reason to expect destination States to ratify. By contrast, in origin countries, ratification is a strategy to protect citizens, especially those who live abroad, but also those who are left behind or who may emigrate at some point in the future. It follows that, as the ratification record of the ICMW indicates, only origin States are likely to ratify.

However, the politics of the ICMW also work at the international level: by definition, migration is a phenomenon that concerns more than one country. Even if destination States see it as an issue closely associated with their sovereignty and address migration mostly in a unilateral way, it is difficult not to address this issue at the international level. Yet, it is equally difficult for States not to disagree over this issue and the ICMW thus constitutes a battleground between the North and the South, between origin and destination countries. As noted above, it was strongly backed by origin countries. Many Western and European countries, by contrast, were reluctant to engage in normative standards regarding migrants' rights. ${ }^{43}$ At the time, in the seventies, lessdeveloped countries were hoping to push for a new economic order, especially after the 1973 oil crisis, and migrants' rights were understood as an issue that origin countries could try to impose upon destination States. It follows that, from the beginning, the ICMW was the object of North-South disagreements. This divide is still visible: the fact that State parties are almost exclusively from the South shows that, more than forty years after the idea of an international convention on migrants' rights was first proposed, the issue remains highly contested.

This is exemplified by the question of irregular migration. Initial drafts of the Convention were rejected because they were seen as almost encouraging irregular migration in a way that would benefit origin countries' economies exclusively. ${ }^{44}$ The final draft is more consensual but nevertheless grants rights to irregular migrants in a way that is much more explicit than in other human rights instruments. While the Convention establishes a distinction between regular and irregular migrants, with more rights for the former than the latter, it does not permit reservations that would exclude irregular migrants from the scope of the Convention (Article 88). From a labour protection or human rights perspective this makes a lot of sense. However, from the perspective of destination States, this can be interpreted as challenging their right to control and regulate migrants' movements and as an indication that the ICMW is predominantly based on

43 Battistella, G, supra nt 7.

44 Böhning, R, "The ILO and the New UN Convention on Migrant Workers: The Past and Future" 25(4) International Migration Review (1991) 698. 
origin countries' interests. ${ }^{45}$ Even if, legally speaking, the ICMW does not contain many new rights its spirit would be biased in favour of one side of the migration process, leading to an automatic rejection by the other side.

This section further addresses the international politics of the ICMW by looking at two issues: the work of the UN on migration and the recommendations by intergovernmental organisations; and the situation of 'in-between' countries that cut across the North-South divide and shed a particular light on the ICMW.

\section{A. The ambivalent role of the UN system}

The attitude of the UN system towards the ICMW is a clear indication of its political nature. On the one hand, the UN system has been crucial in making its adoption possible. Even if the Convention lacked the support of influential States from the beginning of the drafting process, it is very difficult for such a process to actually stop. Somehow, once it has started, it goes on. For governments, and especially for those in developed countries that find themselves in a minority in a setting like the UN General Assembly, it is not easy to justify why the drafting of a human rights treaty should be interrupted. As Battistella recalls, Western governments opted for letting the process go to its end, while at the same time making quite clear that they would not feel bound by the Convention after adoption. ${ }^{46}$ This attitude makes it possible for such a treaty to be adopted (even if not subsequently ratified). After adoption, the UN system helps the ICMW to continue to exist by routinely producing reports or statements that keep the topic alive in international discussions.

On the other hand, the UN has arguably failed to fully support the ICMW. UN agencies, including the ILO, have historically done little to promote their respective conventions on migrant workers. The text of the ICMW was reportedly not available publicly until 1996, six years after it was adopted ${ }^{47}$ Several observers also noted the unpreparedness of the UN after 1990 and its inability to back the ICMW in the early ratification years. ${ }^{48}$ Part of the problem lies in internal disagreements. As noted above, the ILO was initially in charge of migrant workers' issues but it then proved reluctant to let the UN take over and to put its expertise and resources at the disposal of the ICMW. However, the UN also faced more fundamental difficulties: the leading role played by origin States in the drafting process limited the support from powerful (and wealthy) governments, resulting in a lack of political support and financial resources.

This is quite visible in the evolution of intergovernmental debates over migration. Over the past two decades, the dominant approach among the UN and other intergovernmental organisations (such as the International Organization for Migration $[\mathrm{IOM}])$ has become increasingly centred on the economic benefits of migration, as well as on the crime and security implications of unauthorised migration. This has resulted in an emphasis on the so-called 'migration and development' nexus, as well as on phenomena such as human trafficking. The ICMW is hardly mentioned in these discussions and sometimes even viewed with explicit scepticism as it would be at odds with this 'managerial' logic. ${ }^{49}$ Moreover, many of today's international initiatives on migration (for

45 Van Krieken, P, "Migrants' Rights and the Law of the Sea: Further Efforts to Ensure Universal Participation" 45(1) International Migration (2007) 209.

46 Battistella, G, supra nt 7.

47 Taran, P, supra nt 32, 164.

48 See Taran, supra nt 32, 164-165; Grange, $M$ and d'Auchamp, M, supra nt 11, 76-77.

49 Goodwin-Gill, GS, "Migrant Rights and Managed Migration" in Chetail, V, ed, Mondialisation, Migration et Droits de L'homme: Le Droit International en Question / Globalisation, Migration and Human Rights: International Law under Review (Bruylant, Brussels, 2007). 
instance the Global Forum on Migration and Development) are State-owned, reflecting governments' reluctance to give the UN too important a role therein. This also goes along with an emphasis on soft law instruments to regulate migration, rather than on hard international law treaties. ${ }^{50}$ Finally, States have displayed a clear preference for bilateral or regional approaches to migration governance, rather than for genuinely multilateral initiatives. $^{51}$

The picture is therefore ambivalent: without the ILO or the UN there would be no international standards pertaining to migrant workers. However, even among the organisations that are tasked with promoting and monitoring these legal instruments there are deep political disagreements on how to apprehend migration and on the emphasis that should be put on human rights. This lack of political support is a major obstacle to increased acceptance of the ICMW and cannot be addressed without a better recognition of the political dimension of the Convention. Overall, the UN and other international organisations tend to downplay the political sensitivity of migration-related issues by, for example, arguing that it can be addressed in a way that is beneficial for all or that helping migrants is merely a humanitarian issue disconnected from economic and labour market forces. This has of course to do with the intergovernmental setting in which international organisations work, which makes it difficult to openly address political and sensitive topics. Furthermore, such depolitisation makes it impossible to recognise that migration policy is marked by core political (or even moral) issues that cannot be left unaddressed. ${ }^{52}$

This points to the need for renewed political coalitions around the Convention. While advocates of migrants' rights (origin States, unions or NGOs) traditionally have limited bargaining power, they may nevertheless find it possible to promote the ICMW, particularly by relying on the legitimacy of human rights in Western democratic culture and in supranational or international institutions (such as the European Union, see below). As this discussion highlights, there are few obstacles to the ICMW and in developed countries the refusal to ratify a human rights treaty is potentially difficult to justify. As long as the issue is not raised or raised with little insistency it is possible to ignore it. This has been the case as the Convention has long suffered from very low levels of awareness and visibility. However, this situation is changing and while the very topic of migrants' rights will remain politically contested and sensitive there might be room for envisaging a brighter future for the ICMW. ${ }^{53}$

On a different note, this political approach to the ICMW points to the fact that rights rarely exist in an abstract and absolute manner; they are always the object of bargains over the extent to which they are to be implemented and therefore subject to ongoing political negotiations. It follows that, as Alba writes, 'much of the discussion of migrant abuse concerns rights not being enforced, rather than their absence on paper' ${ }^{54}$

50 Grant, S, "GCIM Report: Defining an "Ethical Compass" for International Migration Policy" 44(1) International Migration (2006) 13-19; Pécoud, A, "The UN Convention on Migrant Workers' Rights and International Migration Management" 23(3) Global Society: Journal of Interdisciplinary International Relations (2009) 333-350.

51 UN General Assembly, Human Rights of Migrants: Notes by the Secretary General, 7 August 2013, (Committee 5) A/68/283.

52 Pécoud, A, supra nt 33.

53 Desmond, A, "The Triangle that Could Square the Circle? The UN International Convention on the Protection of the Rights of All Migrant Workers and Members of Their Families, the EU and the Universal Periodic Review" 17(1) European Journal of Migration and Law (2015) 36; Piper, N and Rother, S, "Let's Argue about Migration: Advancing a Right(s) Discourse via Communicative Opportunities" 33(9) Third World Quarterly (2012) 1735.

54 Alba, F, "Martin Ruhs' The Price of Rights: Flexible accommodation vs. all-encompassing norms?" 3(2) Migration Studies (2015) 295. 
Measuring rights is therefore difficult as the real issue lies less in their formal existence rather than in their translation into practice, especially when it comes to undocumented migrants. In this respect, the Convention may not change the content of the rights available to migrants (at least not in Western developed countries); but it can have an impact on the context in which different actors (government, migrants, employers, unions, civil society) interact and negotiate over the way rights are made available. This makes clear that migrants' access to rights is a political issue, which depends upon the power relations between the actors that play a role therein.

\section{B. In-between States}

Another observation that can be made concerns the grey zone in which certain States find (or have found) themselves with respect to ratifying the ICMW. While the Convention has been the object of disagreements between the North and the South, the composition of these two blocks is sometimes unclear and has changed over time. It follows that some States are not clearly on one side only and are characterised by an in-between nature that makes their relationship to the ICMW more complex. This is not to say that the divide between origin and destination countries, or between developed and less-developed States, has disappeared; there are still very real diverging interests among countries when it comes to the global politics of migration. Rather, it is to suggest that those States that find themselves in this grey zone can shed light on situations of non-ratification that are complex and not attributable to a single factor.

One can first mention States that, while traditionally on the sending side of the migration process, have gradually become destination countries. The best example is probably Mexico, which was one of the chief advocates of the ICMW from the very beginning and ratified it in 1999. As Diaz and Kuhner recall, this was part of a strategy to protect Mexican migrants in the United States. Yet, Mexico is now also a destination and a transit country. This raises major challenges, however, as these authors further note, 'Mexico is in a position to show the international community that a state which both receives and sends migrants can ratify and comply with the Convention'. ${ }^{55}$ More or less similar observations could be made in relation to other non-Western countries, such as Morocco or Argentina.

What is perhaps less known is that several European countries used to be in a relatively similar situation. Southern European countries, in particular, were predominantly States of origin when the ICMW was first conceived; when it was eventually adopted, they had moved to the destination side. Portugal and Italy, for example, had ratified both ILO Conventions by the early eighties. Yet, in the nineties, their concerns were no longer centred on the protection of their emigrants; they had started to experience immigration, which changed their attitude towards the Convention. ${ }^{56}$ It is even reported that they used their own experience to warn other countries that were considering ratification, especially in North Africa, arguing that sooner or later they would have to apply the ICMW to their own immigrants - and that they should be cautious when committing to such standards. ${ }^{57}$ According to several observers, Italy considered ratification quite seriously and did not see major obstacles; the main problem, rather, seems to have arisen from its political instability, specifically frequent changes of governments and the difficulty of ensuring consistency in policy orientations. ${ }^{58}$

\footnotetext{
5 Diaz, G and Kuhner, G, supra nt 13, 241.

56 Touzenis, K, supra nt 21.

57 Interview with Graziano Battistella, Scalabrini Migration Centre, Quezon, Philippines, June 2015.

58 Interview with Mariette Grange, human rights practitioner, Geneva, Switzerland, March 2015.
} 
In Portugal, the situation appears to have been quite different, as the country was reportedly discouraged from ratifying in the context of its accession to the EU (which took place in 1986). This is extremely difficult to document: in principle, there is no conflict between EU membership and ratification of an international human rights treaty and EU discussions on this matter are highly unlikely to be formal or public. It remains, however, that several observers noted the unsupportive role played by the EU: from the authors' personal experience, it appears that most of the people interested in the ICRMW heard rumours that the EU instructed new Member States, or potential candidates to EUmembership, not to ratify. Given the absence of in-depth research on this sensitive topic, it is difficult to determine the extent to which this assessment is correct. What is clear is that EU States function as a kind of benchmark: countries in the EU periphery attempt to change their policies and legislation according to European and EU standards and are actively encouraged to do so through EU support or by intergovernmental bodies (like the International Centre for Migration Policy Development [ICMPD]). ${ }^{59}$ As a result, governments that have recently joined the EU, or that aim at doing so, will not consider the ICMW as a priority and will prefer copying what other EU States do. Whether this means that some of these States genuinely wanted to ratify but were kept from doing so because of EU pressures is uncertain.

What is certain, however, is that the process of European integration did not contribute to broader acceptance of the ICMW. Migration became an issue for Europe at more or less the same time as the ICRMW was finalised and adopted. The 1985 Schengen treaty, in particular, paved the way for a borderless zone in the EU, while the 1999 Amsterdam treaty formally established migration as a matter of competence for the EU. While this did not create an EU immigration policy (which, to a large extent, still does not exist), it nevertheless made clear that the growing interdependencies between European States were inevitably going to impact migration dynamics. As MacDonald and Cholewinski observe, this made for a convenient 'EU alibi' as Member States could justify the non-ratification of the ICMW by pointing to the need of a European strategy on that matter. ${ }^{60}$

\section{Conclusion}

The ICMW has, from the start, been the object of heated debate. Of the ten core international human rights instruments, it is clearly the most controversial and contested. While it would be erroneous to consider that other human rights treaties are fully consensual, ${ }^{61}$ the unease with the ICMW reflects a broader unease with migration at large and with the role migrants should play in destination societies. It also reflects a kind of 'sedentary' assumption according to which people should 'normally' remain in their own State, $^{62}$ as well as the often implicit assumption that nationals are somehow more deserving than foreigners and should have priority access to human rights. These

59 European influence can even be felt far away from its neighborhood. Piper documents that Japan and the Republic of Korea, for example, tend to look at the attitude of European countries before developing their own strategy in terms of human rights and of the ratification of international standards. Piper, N, supra nt $13,177$.

${ }^{60}$ MacDonald, E and Cholewinski, R, supra nt 18.

61 Taran recalls that acceptance of the ICMW was made even more difficult by the fact that it was adopted at a time when human rights became more openly contested, particularly during the 1993 Vienna World Conference on Human Rights. Taran, P, supra nt 32, 157-160.

62 Bakewell, O, "Keeping Them in Their Place: The Ambivalent Relationship between Development and Migration in Africa" 29(7) Third World Quarterly (2008) 1341. 
controversies over migrants' rights have, as argued in this article, done much harm to the ICMW - to the extent that it remains, up until today, a much under-used legal instrument.

Despite this, the controversial nature of the ICMW could also be viewed as a good thing. It clearly indicates that migration and the rights that should be granted to migrant workers are political matters. One can argue at length about the legal and economic implications of ratifying the Convention, but as this article tried to show, the core disagreement is of a political nature. Human rights are sometimes characterised by a kind of depoliticisation process, whereby everybody seems to mildly agree on their relevance while not necessarily translating this into practice. This is not the case with the ICMW, which represents one of the very few international codifications of human rights to be openly contested by even the most human rights-friendly countries. This has often remained implicit and unnoticed, as the low visibility of the Convention has meant that governments in Destination States could avoid clearly positioning themselves.

As this changes, the rights of migrant workers may become the new frontier for human rights and for social and political progress at large. In a world in which many countries in the global South face persistent economic disadvantage and socio-political instability, migration is likely to remain a global trend, with a lasting impact on destination societies. The existing political responses to mobility, such as the neat distinction between 'economic' migrants and 'political' refugees, will prove growingly inadequate and more obviously so. This is, of course, not new. However, this 'age of migration' ${ }^{63}$ will make the key questions raised by the ICMW growingly acute: issues such as the rights of nonnationals, their role in the labour market, the recognition of their presence and needs, the responsibility of States and employers and the need for international cooperation will become increasingly difficult to ignore. Importantly, and as early $20^{\text {th }}$-century efforts by the ILO already made clear, these do not only concern foreigners or migrants but all workers and members of both origin and destination societies. To a very large extent, the appropriate political framework to address these questions remains to be invented. There is no guarantee that it will emerge soon, nor is it certain that the Convention will play a role therein. However, by envisaging a world in which migrants and foreign workers have full access to human rights, the ICMW at least raises the right questions and could eventually emerge as what it is, namely a symbol for less unfair and imbalanced approaches to international migration and global affairs.

$*$

www.grojil.org

63 Castles, S, de Haas, H and Miller, M, The Age of Migration. International Population Movements in the Modern World (Palgrave, Basingstoke, 2013). 